\title{
JUDEX FACTI MAHKAMAH SYAR'IYAH PROVINSI ACEH DALAM MENANGANI PERKARA CERAI TALAK (Analisis Putusan Nomor 45/Pdt.G/2017/MS.Aceh)
}

\author{
Hidayatullah, Burhanuddin
}

Fakultas Syariah dan Hukum, UIN Sunan Gunung Djati Bandung

E-mail : hidayatullah05071997@gmail.com

\begin{abstract}
The judiciary is organized into two levels, the first level of justice is Religious Court/Syar'iyah Court, and the court of appeal is the Religious High Court/Provincial Syar'iyah Court. These two trials are referred to as judex facti. The judex facti function is carried out through several stages, is: formulating facts, looking for cause and effect relationships and figuring out probabilities. So, the background of this research is related to the application of judex facti in Aceh Syar'iyah Court. Based on the analysis of the data carried out, it is concluded that the Judex Facti of the Aceh Syar'iyah Court in trying and deciding divorce case Number 45/Pdt.G/2017/MS.Aceh has tried to apply in accordance with the principles of law and legislation in force. That is in the ruling the Aceh Syar'iyah Court panel of judges had given maximum consideration to the reasons for the comparison in filing an appeal. However, there are still shortcomings and anomalies related to the reasons for the comparison in submitting a request so that the 10-grand dowry that has not been paid in full is not granted by the panel of judges of the Syar'iyah Court. Because of this, the judiciary of the Aceh Syar'iyah Court was judged to have shortcomings and was not optimal in applying the law. Although in authority the panel of judges may not grant the demands of the comparator as long as they do not conflict with applicable laws and regulations. If judged from the whole, the judex facti of the Aceh Syar'iyah Court has implemented it in accordance with the applicable laws and regulations.
\end{abstract}

Keywords: Divorce, Judex Facti, Material Law, Formal Law, and Legal Considerations.

\begin{abstract}
Abstrak
Peradilan disusun dalam dua tingkatan, yaitu peradilan tingkat pertama, yakni Pengadilan Agama/Mahkamah Syar'iyah dan peradilan tingkat banding, yakni Pengadilan Tinggi Agama/Mahkamah Syar'iyah Provinsi. Dua peradilan ini disebut sebagai judex facti. Fungsi judex facti dilakukan melalui beberapa tahapan, yaitu: merumuskan fakta, mencari hubungan sebab akibat dan mereka-reka probabilitas. Jadi, Latar belakang dari Penelitian ini adalah terkait penerapan judex facti di Mahkamah Syar'iyah Aceh. Analisis data penelitian ini dengan sifat deskriptif-analitis. Berdasarkan analisa data yang dilakukan, maka diperoleh kesimpulan bahwa Judex Facti Mahkamah Syar'iyah Aceh dalam mengadili dan memutuskan perkara Nomor 45/Pdt.G/2017/MS.Aceh tentang perkara cerai talak sudah berusaha menerapkan sesuai dengan asas-asas hukum dan perundangundangan yang berlaku.Yaitu dalam putusan tersebut majelis hakim Mahkamah Syar'iyah Aceh telah mempertimbangkan secara maksimal alasan pembanding dalam mengajukan banding. Akan tetapi tetap ada kekurangan dan keganjalan terkait alasan pembanding dalam mengajukan permintaan agar terbanding melunasi mahar 10 mayam yang belum
\end{abstract}


dilunaskan tidak dikabulkan oleh majelis hakim Mahkamah Syar'iyah. Karena hal tersebut, judex facti Mahkamah Syar'iyah Aceh dinilai masih terdapat kekurangan dan belum maksimal dalam menerapkan hukumnya. Meskipun secara kewenangan majelis hakim boleh tidak mengabulkan tuntutan dari pembanding asalkan tidak bertentangan dengan peraturan perundang-undangan yang berlaku. Jika dinilai dari keseluruhan, judex facti Mahkamah Syar'iyah Aceh sudah menerapkan sesuai dengan peraturan perundangundangan yang berlaku.

Kata Kunci: Cerai Talak, Judex Facti, Hukum Materiil, Hukum Formil, dan Pertimbangan Hukum.

\section{PENDAHULUAN}

Indonesia sebagai negara hukum sesuai dengan Pancasila dan Undang-Undang Dasar Negara Republik Indonesia Tahun 1945, yang memiliki tujuan untuk mewujudkan ketertiban, keadilan dan kesejahteraan dalam berkehidupan berbangsa dan bernegara. Oleh karena itu, hukum yang ada harus ditaati dan dihormati oleh seluruh warga negara, penegak hukum, maupun oleh penguasa negara, sehingga segala tindakan yang dilakukan harus berlandaskan hukum.

Peraturan negara Indonesia ini sendiri ada lembaga kekuasaan kehakiman. Penyelenggaraan kekuasaan kehakiman diatur dalam pasal 18 Undang-Undang Nomor 48 Tahun 2009 tentang Kekuasaan Kehakiman yang berbunyi: “Kekuasaan Kehakiman dilakukan oleh sebuah Mahkamah Agung dan badan peradilan yang berada di bawahnya dalam lingkungan peradilan umum, lingkungan peradilan agama, lingkungan peradilan militer, lingkungan peradilan tata usaha negara, dan oleh sebuah Mahkamah Konstitusi". ${ }^{1}$

Wewenang badan peradilan dalam lingkungan peradilan agama diatur dalam pasal 49 Undang-Undang Nomor 3 Tahun 2006 tentang Peradilan Agama yang menyatakan bahwa: "Pengadilan Agama bertugas dan berwenang memeriksa, memutus, dan menyelesaikan perkara di tingkat pertama antara orang-orang yang beragama Islam di bidang: perkawinan, waris, wasiat, hibah, wakaf, zakat, infaq, shadaqah dan ekonomi syariah". ${ }^{2}$

Dalam lingkungan peradilan agama, peradilan disusun dalam dua tingkatan, yaitu peradilan tingkat pertama, yakni Pengadilan Agama dan peradilan tingkat

\footnotetext{
${ }^{1}$ Pasal 18 Undang-Undang Nomor 48 Tahun 2009 Tentang Peradilan Agama.

2 Pasal 49 Undang-Undang Nomor 3 Tahun 2006 Tentang Peradilan Agama.
} 
banding, yakni Pengadilan Tinggi Agama. Dua peradilan ini disebut sebagai judex facti ${ }^{3}$, sedangkan Mahkamah Agung mempunyai sebagai fungsi sebagai judex juris ${ }^{4}$.

Hakim pada peradilan tingkat pertama dan peradilan banding memeriksa fakta hukum sebagai alas perkara yang kemudian mencocokan fakta hukum tersebut terhadap hukum yang menjadi landasan yuridis berperkara. Fakta hukum adalah fakta yang bersentuhan dengan hukum, yakni fakta yang diatur oleh hukum, baik mengenai pembuktiannya, substansinya, maupun akibat hukumnya. Fakta hukum diklasifikasikan menjadi dua jenis, yaitu peristiwa hukum dan perbuatan hukum. ${ }^{5}$

Fungsi judex facti dilakukan melalui beberapa tahapan, yaitu; merumuskan fakta, mencari hubungan sebab akibat dan mereka-reka probabilitas. Langkah-langkah pemeriksaan perkara seperti ini merupakan mekanisme pemeriksaan perkara dalam lingkup judex facti. ${ }^{6}$ Peradilan tingkat banding merupakan peradilan judex facti tingkat kedua. Fungsi ini melekat, karena badan peradilan tingkat banding mempunyai wewenang melakukan koreksi terhadap putusan pengadilan agama, bertindak melakukan pemeriksaan ulang terhadap perkara secara keseluruhan, sebagaimana diatur dalam pasal 6 Undang-Undang Nomor 20 Tahun 1947 tentang Pengadilan Peradilan Ulangan, yang menyatakan bahwa: "Dari putusan-putusan Pengadilan Negeri di Jawa dan Madura tentang perkara perdata, yang tidak ternyata, bahwa besarnya harga gugat ialah seratus rupiah atau kurang, oleh salah satu dari pihak-pihak (partijen) yang berkepentingan dapat diminta, supaya pemeriksaan perkara diulangi oleh Pengadilan Tinggi yang berkuasa dalam daerah masing-masing."

Fungsi judex facti pengadilan banding juga diatur pada pasal 15 ayat (1) UndangUndang Nomor 20 Tahun 1947 tentang Pengadilan Peradilan Ulangan yang menyatakan: "Pengadilan Tinggi dalam pemeriksaan ulangan memeriksa dan memutuskan dengan tiga hakim, jika dipandang perlu, dengan mendengar sendiri kedua belah pihak atau saksi".

Wewenang ini dipertegas oleh Mahkamah Agung melalui putusannya Nomor 951 K/Sip/1973, tanggal 9 Oktober 1975 yang menyatakan: “Cara pemeriksaan perkara perdata di tingkat banding-pengadilan tinggi yang hanya memeriksa keberatankeberatan yang diajukan oleh pembanding saja, adalah salah. Seharusnya Majelis

${ }^{3}$ Judex facti merupakan kewenangan hakim dalam memeriksa dan memutus perkara berdasarkan fakta.

${ }^{4}$ Judex juris, artinya Mahkamah Agung hanya mempertimbangkan masalah hukum. Dalam tingkat kasasi, hakim hanya memeriksa apakah putusan tersebut sesuai dengan hukum atau masalah penerapan hukum, dan tidak memeriksa fakta perkara.

${ }^{5}$ A. Mukti Arto, Pembaharuan Hukum Islam melalui Putusan Hakim, (Yogyakarta: Pustaka Pelajar, 2015), hlm. 43.

${ }^{6}$ Moh. Amir Hamzah, Hukum Acara Perdata Peradilan Tingkat Banding, (Malang: Setara Press, 2013), hlm. 5. 
Hakim Banding juga melakukan pemeriksaan ulang atas seluruh perkara tersebut, baik faktanya, maupun penerapan hukumnya yang telah diputuskan oleh hakim pertama". ${ }^{7}$

Demikian juga dalam putusan Mahkamah Agung Nomor 194 K/Sip/1973, tanggal 30 November 1976 dinyatakan bahwa: "Pengadilan Tinggi sebagai Peradilan tingkat banding, dalam memeriksa perkara perdata yang dimohon banding, harus memeriksa dan memberikan putusan perkara tersebut secara keseluruhannya, baik yang konvensi $^{8}$ maupun yang rekovensi ${ }^{9}$ yang telah diputus oleh peradilan tingkat pertama" ${ }^{10}$

Dipertegaskan lagi dalam putusan Mahkamah Agung Nomor 3136 K/Sip/1983 juga dinyatakan bahwa: “..... sesuai ketentuan pasal 15 ayat (1) UU No. 20 Tahun 1947, pengadilan tinggi. berwenang melakukan sendiri pemeriksaan tambahan, bahkan cara yang demikian lebih efektif karena pengadilan tinggi lebih tau hal-hal apa saja yang hendak diperiksa, namun jika pengadilan hendak melakukan sendiri pemeriksaan tambahan langsung kepada para pihak harus benar-benar dipertimbangkan faktor biaya yang harus dipikul para pihak. Sehubungan dengan itu, tidak mutlak pelaksanaan pemeriksaan tambahan mesti didelegasikan pengadilan tinggi kepada pengadilan negeri".

Walaupun peradilan banding merupakan peradilan judex facti tingkat kedua, akan tetapi dalam praktik beracara (yaitu dalam proses pemeriksaan perkara) yang telah berjalan selama ini berpedoman pada Pasal 357 Reglement op de Burgelijke Rechtsvordering $(\mathrm{Rv})^{11}$. "Perkara kemudian oleh Hakim Banding yang bersangkutan tanpa banyak proses diputus berdasarkan surat-surat saja, tetapi ia berwenang sebelum menjatuhkan putusan akhir untuk memberikan putusan persiapan atau putusan sela".

Menurut M. Yahya Harahap, alasan pengadilan tingkat banding menjadikan Pasal 357 Rv sebagai pedoman berdasarkan kebutuhan beracara, karena penerapannya dianggap sangat bermanfaat menjadi landasan beracara (process doelmatigheid). ${ }^{12}$

Pertimbangan Hukum pada putusan Nomor 45/Pdt.G/2017/MS.Aceh tentang Cerai Talak ini; bahwa, judex facti Mahkamah Syar'iyah Banda Aceh telah salah dan keliru dalam penerapan hukumnya dalam perkara a quo, tentang mengabulkan permohonan Pemohon sebagaimana dalam putusan perkara a quo judex facti Mahkamah Syar'iyah Banda Aceh tidak mempertimbangkan tentang mahar Termohon yang belum

${ }^{7}$ Hulman Panjaitan, Kumpulan Kaidah Hukum Putusan Mahkamah Agung Republik Indonesia Tahun 1953 s/d 2008 Berdasarkan Penggolongannya, (Jakarta: Prenadamedia Group, 2016), hlm. 160.

${ }^{8}$ Istilah konvensi sebenarnya merupakan istilah untuk menyebut gugatan awal atau asli.

${ }_{9}^{9}$ Rekovensi adalah gugatan balik yang disampaikan oleh tergugat sehubungan dengan gugatan penggugat.

${ }^{10}$ Human Panjaitan, Kumpulan Kaidah Hukum ......., hlm. 160.

${ }^{11}$ Reglement op de Burgelijke Rechtsvordering (Rv) atau Reglemen Hukum Acara Perdata yang berlaku untuk Golongan Eropa.

${ }^{12}$ M. Yahya Harahap, Kekuasaan Pengadilan Tinggi dan Proses Pemeriksaan Perkara Perdata dalam Tingkat Banding, (Jakarta: Sinar Grafika, 2006), hlm. 112.

64 Jurnal AL-Ahwal Al-Syakhsiyyah : Jurnal Hukum Keluarga dan Peradilan Islam 
dilunasi oleh Pemohon sebesar 10 mayam emas lagi dan kewajiban Pemohon terhadap Termohon sebelum menjatuhkan talak didepan sidang Mahkamah Syar'iyah Banda Aceh dan hal tersebut sama sekali tidak dipertimbangkan oleh judex facti Mahkamah Syar'iyah Banda Aceh dalam mengadili dan memutus perkara a quo dimohonkan banding yang berakibat Termohon telah sangat dirugikan sebab hal tersebut telah Termohon kemukakan dalam jawaban semula dan juga telah didalilkan kembali oleh kuasa hukum.

Termohon dalam Rekonvensi terhadap hutang mahar Termohon/Penggugat Rekonvensi pada Pemohon Konvensi/Tergugat Rekonvensi sebesar 10 (sepuluh) mayam emas lagi yang belum dilunasi oleh Pemohon Konvensi/Tergugat Rekonvensi, sehingga baik pertimbangan hukum maupun amar putusan dalam perkara a quo yang dipertimbangkan dan diputuskan oleh judex facti Mahkamah Syar'iyah Banda Aceh sangatlah salah dan keliru, karena Putusan Mahkamah Syar'iyah Banda Aceh Nomor 0259/Pdt.G/2016/MS.Bna, tanggal 30 Maret 2017 tidak didasari pada fakta-fakta yang terungkap di persidangan, untuk itu cukup beralasan hukum bagi Majelis Hakim Mahkamah Syar'iyah Aceh yang memeriksa dan mengadili perkara yang dimohonkan banding ini, untuk membatalkan Putusan Mahkamah Syar'iyah Banda Aceh Nomor 0259/Pdt.G/2016/MS.Bna, tanggal 30 Maret 2017 yang dimohonkan banding serta untuk mengabulkan permohonan banding dari Pembanding dan mengadili sendiri dengan menetapkan Pemohon untuk membayar sebesar 10 (sepuluh) mayam emas kawin kepada Termohon yang belum dilunasi oleh Pemohon;

Bahwa, judex facti Mahkamah Syar'iyah Banda Aceh dalam pertimbangan hukumnya, menghukum Pemohon untuk membayar atau memberikan kepada Termohon nafkah iddah, selama masa iddah Rp. 5.000.000,- (lima juta rupiah), mut'ah sejumlah Rp. 3.000.000,- (tiga juta rupiah) dan kiswah sejumlah Rp. 3.000.000,- (tiga juta rupiah) adalah pertimbangan hukum dan amar putusan yang tidak adil dan terhadap putusan perkara a quo tersebut sangatlah keliru dalam penerapan hukumnya, sebab dalam rekonvensi Termohon/Penggugat Rekovensi telah mengajukan melalui kuasa hukum Termohon meskipun terlambat, karena Termohon sebelumnya tidak mengetahui hukum acara yang berlaku namun terlepas dari itu terhadap putusan a quo jauh sekali dari tuntutan Penggugat Rekonvensi/Termohon konvensi sebab mengingat tentang situasi dan kondisi harga barang dan kebutuhan hidup untuk saat itu di Kota Banda Aceh sangatlah melonjak, dan tidak stabil, untuk itu cukup beralasan hukum bagi Majelis Hakim Mahkamah Syar'iyah Aceh yang memeriksa dan mengadili perkara yang dimohonkan banding ini, untuk mengabulkan permohonan banding dari Pembanding dan mengadili sendiri menghukum Tergugat Rekonvensi untuk membayar/memberikan kepada Penggugat Rekonvensi/Termohon Konvensi berupa :

1. Nafkah iddah, selama masa iddah Rp. 20.000.000,- (dua puluh juta rupiah);

2. Mut'ah sejumlah Rp. 20.000.000,- (dua puluh juta rupiah); 
3. Kiswah sejumlah Rp. 20..000.000,- (dua puluh juta rupiah);

Dalam kasus ini, Majelis Hakim pada tingkat pertama dan banding yaitu di Mahkamah Syar'iyah Banda Aceh dan Mahkamah Syar'iyah Aceh Provinsi memiliki pertimbangan hukum yang berbeda, yaitu disebabkan judex facti dalam penerapan hukumnya dalam perkara cerai talak. Majelis Hakim pada Mahkamah Syar'iyah Banda Aceh telah salah dan keliru dalam penerapan hukumnya. Sehingga Mahkamah Syar'iyah Provinsi Aceh atau Pengadilan tingkat Banding memutuskan sendiri perkara cerai talak ini.

Berdasarkan uraian tersebut di atas, penulis merasa tertarik untuk melakukan analisis hukum atas putusan Mahkamah Syar'iyah provinsi Aceh, mengenai apa yang menjadi dasar pertimbangan hukum majelis hakim tingkat banding ini. Secara umum, penelitian ini bertujuan untuk menjelaskan secara luas fungsi judex facti dalam penerapan hukumnya di Pengadilan Agama/ Mahkamah Syar'iyah tingkat pertama dan Pengadilan Tinggi Agama/Mahkamah Syar'iyah Tingkat Banding.

Adapun secara khusus, tujuan penelitian ini adalah sebagai berikut, pertama Untuk mengetahui analisis hukum materiil dan hukum formil terhadap putusan Mahkamah Syar'iyah Aceh nomor perkara 45/Pdt.G/2017/MS.Aceh tentang cerai talak. Kedua Untuk mengetahui dasar pertimbangan hukum yang digunakan majelis hakim Mahkamah Syar'iyah Provinsi Aceh dalam putusan nomor 45/Pdt.G/2017/MS.Aceh.

\section{METODE PENELITIAN}

Penelitian ini menggunakan metode Content Analysis (analisis isi), yaitu suatu metode dengan cara menafsirkan isi putusan berdasarkan pertimbangan hakim untuk mendapat gambaran mengenai isi dari putusan atau intinya didasarkan pada sumber dokumen atau bahan bacaan.

Dalam penelitian ini, penulis menentukan tempat penelitian yaitu di Mahkamah Syar'iyah Provinsi Aceh. Sumber data dalam penelitian ini diperoleh dengan sumber data primer dan sekunder. Sumber data primer yang digunakan penulis da la m pene lit ia n ini yaitu berupa dokumen Putusan Nomor 45/Pdt.G/2017/Ms.Aceh tentang Cerai Talak. Sedangkan sumber data sekunder yaitu berupa buku, skripsi, makalah, jurnal dan termasuk website yang ada hubungannya dengan penelitian serta dokumendokumen lain yang berkenaan dengan pelaksanaan penelitian ini.

Adapun teknik pengumpulan data yang digunakan penulis dalam penelitian ini antara lain teknik dokumentasi dan studi kepustakaan. Teknik dokumentasi yaitu berupa mencari salinan putusan Mahkamah Syar'iyah nomor 45/Pdt.G/2017/MS.Aceh tentang perkara cerai talak di website Mahkamah Syar'iyah Provinsi Aceh. Sedangkan teknik studi kepustakaan yaitu didapatkan dari buku-buku yang ada hubungannya dengan penelitian. 
Dalam penelitian ini, penulis akan melakukan analisis data dengan sifat deskriptif-analitis. Deskriptif berarti menggambarkan data primer (data yang telah penulis dapatkan di Mahkamah Syar'iyah Provinsi Aceh) dan juga pemaparan data sekunder terkait fungsi judex facti Mahkamah Syar'iyah Banda Aceh dan Mahkamah Syar'iyah Provinsi Aceh dalam menangani perkara cerai talak, selanjutnya dilakukan analisis terhadap hasil penelitian dengan tinjauan cita hukum keadilan, kepastian hukum, dan kemanfaatan. Jadi, yang dimaksud deskriptif-analitis disini adalah data yang dinyatakan dalam bentuk tulisan dan pernyataan yang nyata yang diteliti dan dipelajari sebagai sesuatu yang utuh.

\section{PEMBAHASAN DAN HASIL PENELITIAN}

Upaya Hukum Banding yaitu suatu upaya yang diberikan oleh undang-undang kepada semua pihak yang sedang berperkara di pengadilan untuk mengajukan perlawanan terhadap keputusan hakim, ${ }^{13}$ mohon supaya perkara yang telah diputus oleh pengadilan tingkat pertama diperiksa ulang oleh pengadilan yang lebih tinggi (tingkat banding), karena merasa belum puas dengan keputusan pengadilan tingkat pertama, ${ }^{14}$ atau dengan kata lain suatu usaha bagi setiap pribadi atau badan hukum yang merasa dirugikan haknya atau atas kepentingannya untuk memperoleh keadilan dan perlindungan/kepastian hukum, menurut cara-cara yang ditetapkan dalam undang-undang. Atas penetapan dan putusan Pengadilan Agama dapat dimintakan banding oleh pihak yang berperkara kecuali apabila undang-undang menentukan lain.

Dalam pengajuan upaya hukum banding di Pengadilan Tinggi Agama/Mahkamah Syar'iyah Provinsi Aceh harus memerhatikan beberapa syarat-syarat dan mekanisme pengajuan banding. Agar pengajuan banding dapat diterima dan berjalan dengan lancar di Pengadilan Tinggi Agama/Mahkamah Syar'iyah Aceh.

Dalam pengajuan banding di Pengadilan Tinggi Agama/Mahkamah Syar'iyah Aceh juga harus memenuhi 2 (dua) syarat yaitu syarat secara hukum formil dan syarat secara hukum materiil. Apabila syarat hukum materill dan formil tidak terpenuhi secara lengkap, maka proses banding akan terjadi kendala seperti ditunda atau pun bisa jadi perkara banding tersebut dapat digugurkan oleh majelis hakim Pengadilan Tinggi Agama/Mahkamah Syar'iyah Provinsi Aceh.

Pengajuan banding tersebut memiliki banyak manfaat:

a. untuk mencegah adanya keputusan yang salah;

b. untuk mencegah adanya hakim yang berpihak kepada salah satu pihak dalam suatu perkara;

13Sarwono. Hukum Acara Perdata Teori dan Praktik, (Jakarta: Sinar Grafika, 2011), hlm. 350.

${ }^{14}$ Mukti Arto, Praktek Perkara Perdata pada Pengadilan Agama, (Yogyakarta: Pustaka Pelajar, 1996). 
c. untuk memicu hakim dalam melaksanakan tugasnya agar supaya dalam menangani suatu perkara dapat bertindak bijaksana dan memberikan keputusan yang adil.

d. untuk mencegah adanya kesewenang-wenangan hakim dalam menangani suatu perkara;

e. untuk terciptanya asas peradilan yang dapat dilaksanakan dengan sederhana, cepat dan biaya ringan;

f. untuk mendidik para hakim menjadi hakim yang professional;

g. untuk memperbaiki keputusan hakim yang salah; ${ }^{15}$

Penelitian ini mendapatkan hasil bahwa secara keseluruhan pihak pembanding dalam mengajukan banding ke Pengadilan Tinggi Agama telah memenuhi syarat hukum formil dan materill. Akan tetapi, dalam hal tuntutan dari termohon/pembanding terkait mahar 10 mayam emas yang belum dilunasi oleh pemohon/terbanding hakim tidak mempertimbangkan dan tidak mengadili tuntutan tersebut. Padahal dalam pasal 178 ayat (2) telah dijelaskan bahwa, "Hakim itu wajib mengadili semua bagian tuntutan". Berdasarkan hukum acara tersebut, maka hakim saya rasa putusan tersebut sudah bertentangan dengan hukum formilnya.

Dalam menerapkan judex facti, Hakim Mahkamah Syar'iyah Provinsi Aceh telah menerapkan dan melaksanakan secara maksimal. Akan tetapi, tetap juga walaupun telah dilaksanakan dan diterapkan secara maksimal ada 2 (dua) unsur terkait keadilan dan kepastian hukum terhadap pembanding belum terpenuhi secara menyeluruh. Namun, kalau dilihat secara keseluruhan hakim telah berusaha adil dan melaksanakan berdasarkan perundang-undangan yang berlaku.

\section{SIMPULAN}

Berdasarkan pembahasan yang telah dijelaskan di atas maka penulis dapat mengambil beberapa kesimpulan: Majelis Hakim Mahkamah Syar'iyah Aceh dalam memutuskan perkara Nomor 45/Pdt.G/2017/MS.Aceh tentang perkara cerai talak tersebut sudah sesuai dengan hukum materiil yang berlaku. Karena perkara tersebut telah memenuhi unsur-unsur dalam Undang-Undang Nomor 7 Tahun 1974, Kompilasi Hukum Islam. Serta telah mengikuti anjuran hukum Islam yaitu surat at-Talaq ayat 6, surat al-Baqarah ayat 228, 231, dan 241.

Secara hukum formil putusan Mahkamah Syar'iyah Aceh telah memutuskan berdasarkan Hukum Acara yang berlaku yaitu Pasal 178 ayat (3) HIR, pasal 54 UndangUndang Nomor 7 Tahun 1989, Undang-Undang Nomor 3 Tahun 2006 dan UndangUndang Nomor 50 Tahun 2009. Akan tetapi dalam segi mengabulkan tuntutan termohon ada sedikit tidak sesuai dengan hukum formil, hal itu berdasarkan Pasal 178

15 Sarwono. Hukum Acara Perdata Teori ....... hlm. 351.

68 Jurnal AL-Ahwal Al-Syakhsiyyah : Jurnal Hukum Keluarga dan Peradilan Islam 
ayat (2) HIR, Hakim Mahkamah Syar'iyah Aceh tidak mengabulkan seluruh tuntutan termohon.

Pertimbangan Hukum yang digunakan majelis hakim dalam memutuskan perkara Nomor 45/Pdt.G/2017/MS.Aceh tentang perkara cerai talak ini adalah ketentuan-ketentuan berdasarkan pasal 19 huruf (f) Peraturan Pemerintah Nomor 9 tahun 1975 jo pasal 116 huru (f) Kompilasi Hukum Islam, pasal 41 huruf (c) UndangUndang Nomor 1 tahun 1974 jo pasal 149, pasal 152, pasal 158, pasal 159 Kompilasi Hukum Islam, dan juga berdasarkan menurut pendapat DR. Wahbah Al- Zuhaily di dalam kitabnya Fiqh Al Islami wa Adillatuhu juz VII. Jadi, Terkait Judex Facti Mahkamah Syar'iyah Aceh dalam menerapkan hukumnya sudah sesuai dengan undang-undang yang berlaku dan telah menjalankan kewenangannya yaitu ex officio dalam menerima, mengadili dan memutuskan perkara cerai talak tersebut. Jadi secara keseluruhan judex facti Hakim Tingkat Banding dalam menangani perkara cerai talak telah menjalankan sesuai dengan Hukum Acara atau formil dan Materiil berdasarkan undang-undang yang berlaku. Dan juga telah menjalankan asas-asas keadilan, kepastian hukum sehingga kedua belah pihak dapat merasakan kemanfaatan.

\section{DAFTAR PUSTAKA}

A. Mukti Arto. 2015. Pembaharuan Hukum Islam melalui Putusan Hakim, Yogyakarta: Pustaka Pelajar.

- 1996. Praktek Perkara Perdata pada Pengadilan Agama, Yogyakarta: Pustaka Pelajar.

Harahap, M. Yahya. 2006. Kekuasaan Pengadilan Tinggi dan Proses Pemeriksaan Perkara Perdata dalam Tingkat Banding, Jakarta: Sinar Grafika.

Moh. Amir Hamzah. 2013. Hukum Acara Perdata Peradilan Tingkat Banding, Malang: Setara Press.

Panjaitan, Hulman. 2016. Kumpulan Kaidah Hukum Putusan Mahkamah Agung Republik Indonesia Tahun 1953 s/d 2008 Berdasarkan Penggolongannya, Jakarta: Prenadamedia Group.

Sarwono. 2011. Hukum Acara Perdata Teori dan Praktik, Jakarta: Sinar Grafika

Undang-Undang Nomor 3 Tahun 2006 tentang Perubahan atas Undang-Undang Nomor 7 Tahun 1989 tentang Peradilan Agama ( Lembaran Negara Republik Indonesia Tahun 2006 Nomor 22, Tambahan Lembaran Negara Republik Indonesia Nomor 4611). 
Volume I, Nomor 01, Maret 2020

Undang-Undang Nomor 7 Tahun 1989 tentang Peradilan Agama (Lembaran Negara Tahun 1989 Nomor 49; Tambahan Lembaran Negara Nomor 3400).

Undang-Undang Republik Indonesia Nomor 48 Tahun 2009 Tentang Kekuasaan Kehakiman 